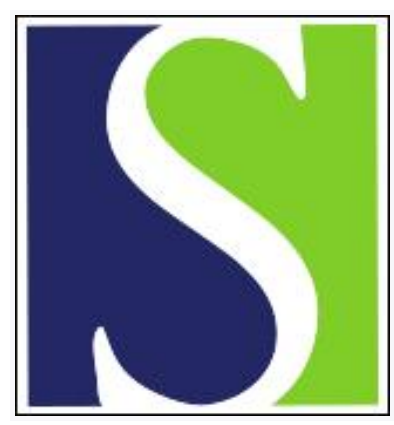

Scand J Work Environ Health 1998;24(1):46-53

https://doi.org/10.5271/sjweh.277

Issue date: Feb 1998

Dementia and occupational exposure to magnetic fields

by Feychting M, Pedersen NL, Svedberg P, Floderus B, Gatz M

The following articles refer to this text: 2001;27(3):161-213;

2002;28(1):42-48; 2004;30 suppl 1:1-80

Key terms: Alzheimer's disease; case-control study; electromagnetic fields; vascular dementia

This article in PubMed: www.ncbi.nlm.nih.gov/pubmed/9562400

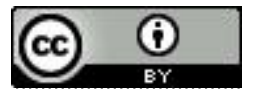




\title{
Dementia and occupational exposure to magnetic fields
}

\author{
by Maria Feychting, PhD, ${ }^{1}$ Nancy L Pedersen, PhD, ${ }^{1,2}$ Pia Svedberg, BA, ${ }^{1}$ Birgitta Floderus, PhD, ${ }^{1,3}$ \\ Margaret Gatz, $P h D^{2}$
}

\begin{abstract}
Feychting M, Pedersen NL, Svedberg P, Floderus B, Gatz M. Dementia and occupational exposure to magnetic fields Scand J Work Environ Health 1998;24(1):46-53.

Objectives The purpose of the present report was to assess whether occupational magnetic field exposure is a risk factor for dementia, in particular for Alzheimer's disease.

Methods Case-control analyses were applied to 77 dementia cases, 55 of whom had Alzheimer's disease, ascertained from the population-based Swedish twin register. Two reference groups were derived, with 228 and 238 persons, respectively. Occupations were linked to a job-exposure matrix based on magnetic field measurements. Primary occupation, last occupation before reference date, and the occupation with the highest magnetic field exposure during the subject's lifetime were evaluated.

Results For primary occupation, all relative risk estimates were close to unity. For last occupation, at the exposure level $\geq 0.2 \mu \mathrm{T}$, a relative risk was found for dementia estimated at 3.3 [95\% confidence interval (95\% CI) 1.3-8.6] and 3.8 (95\% CI 1.4-10.2) for reference groups 1 and 2, respectively. The relative risk for Alzheimer's disease was estimated at 2.4 (95\% CI $0.8-6.9)$ and 2.7 (95\% CI $0.9-7.8)$, respectively. For the occupation with the highest magnetic field exposure, the relative risk estimates were close to unity for reference group 1 and slightly elevated for reference group 2 . The relative risk estimates were greater for the subjects who were younger at onset ( $\leq 75$ years).

Conclusions These results only partially support previous findings, but they indicate that occupational magnetic field exposure may possibly influence the development of dementia.
\end{abstract}

Key terms Alzheimer's disease, case-control study, electromagnetic fields, vascular dementia.

Most researchers agree that Alzheimer's disease has a multifactorial etiology, with influences by multiple genes and multiple environmental agents (1). Risk factors can be summarized in terms of family history and genetic effects, medical history, and environmental exposures, with some risk factors clearly able to be cross-categorized. One of the earliest reported risk factors was positive family history (2), an indicator of possible genetic risk. These early findings have not only been supported by linkage to a number of loci in families with early onset Alzheimer's disease (3-5), but also by case-referent studies of late onset cases $(6,7)$ and twin studies assessing the relative importance of genetic and environmental effects for liability to the disease (8-10). In addition, genetic association studies suggest that some nonlinked loci may also increase susceptibility to Alzheimer's disease $(11,12)$ in persons of advanced age. Nevertheless, the genes thus far identified through linkage analyses explain a very small proportion of all cases of Alzheimer's disease (13).
Among the medical factors suggested to be important for Alzheimer's disease are hypothyroidism (14), past history of depression (15), immune system disorders, and infectious agents (16). There is some evidence that the consumption of nonsteroidal antiinflammatory drugs (17) and estrogen replacement therapy may be protective for Alzheimer's discase (18). Among other factors evaluated, low educational attainment (19), blue-collar occupation, and head trauma with loss of consciousness (20) have received the most consistent empirical support as potential risk factors. There is growing support for a threshold model of dementia, in which multiple risk factors contribute to a lessening of cerebral reserve. Once a threshold of pathology is reached, dementia is manifest (21).

More recently, occupational exposure to extremely lowfrequency magnetic fields has been identified as a potential risk factor for Alzheimer's disease $(22,23)$. Case-referent analyses of 4 study populations, 2 in Finland and 2 in Cali- 
fornia, suggest that workers in occupations with magnetic field exposure estimated to average $0.2-1.0 \mu \mathrm{T}$ or intermittently above $1.0 \mu \mathrm{T}$ had an elevated risk of Alzheimer's disease. Involvement in calcium ion flux, influence on DNA (deoxyribonucleic acid) transcription, and effects on immune system function were presented as possible mechanisms through which exposure to magnetic fields affects pathogenesis resulting in Alzheimer's disease. These studies have some methodological limitations. They were not populationbased, and the referents were either cases with vascular dementia, dementia other than Alzheimer's disease or vascular dementia or they were neighborhood subjects. The exposure assessment was based on expert evaluation of the magnetic field exposure for the subjects' primary lifetime occupation. Furthermore, the results were dependent on relatively few occupational categories (eg, dressmaker, seamstress, and tailor). Finally, risk at varying ages of onset was not estimated. Although intriguing, the question has not been studied in other populations.

The purpose of the present study was to assess whether occupational exposure to magnetic fields is a risk factor for dementia in general, and Alzheimer's disease in particular. Data were taken from a population-based twin study of dementia, the Study of Dementia in Swedish Twins (8). Cases and 2 samples of referents were analyzed to determine the risk of occupational magnetic field exposure. The study offers several advantages when compared with previous studies. Occupational histories were obtained from detailed structured interviews allowing an evaluation of both primary and last occupation, exposure assessment was based on magnetic field measurements, and risk could be determined as a function of age of onset.

\section{Subjects and methods}

\section{Subjects}

The cases and referents in the present report were taken from the Study of Dementia in Swedish Twins (8), which in turn was based on a subsample of the Swedish Adoption/Twin Study of Aging (SATSA), a register-based sample of twins (24). These studies have been described in detail previously, and therefore only a brief description is given in this report. SATSA includes all 961 pairs from the twin register who indicated having been reared apart and a sample of 961 pairs who were reared together, drawn from the twin register matched to the reared apart twins with regard to gender, year of birth, and county of birth. Members of the SATSA panel have been surveyed every 3 years, while a subset of complete pairs aged 50 years and older has participated in inperson cognitive and health assessments on a 3-year rolling schedule $(8,24)$. All members of SATSA born in 1935 or earlier and alive in 1987 were screened for dementia during 1989 - 1991, using either the Mini-Mental State Examination
(MMSE (25) from the most recent wave of in-person testing when available or a telephone screening protocol incorporating a mental status test (26). The response rate was $81 \%$; persons who declined to be screened were excluded from both the case and reference samples. Persons who screened positively were given a complete clinical workup, including physical and neurological evaluation, neuropsychological assessment, laboratory tests, and neuroimaging (27). Diagnoses were assigned at a multidisciplinary consensus conference, following DSM-III-R criteria for dementia (28) and NINCDS/ADRDA criteria for Alzheimer's disease (29). Date of onset was determined by asking the informant the age at which irreversible change first became clearly apparent and by cross-checking medical records. From an initial sample of 1978 subjects, 173 screened positively, resulting in a total of 75 cases ( 38 probable cases of Alzheimer's disease, 11 possible cases of Alzheimer's disease, 12 cases of vascular dementia, and 14 cases of mixed or other dementia diagnoses). All the subjects who participated in the clinical workups, regardless of subsequent diagnosis in 1989 1991, were followed longitudinally every 18 months using the same test battery as in the original clinical workup. The remainder of the SATSA panel has been followed every third year, as has already been described. These 2 forms of longitudinal follow-up have yielded an additional 14 cases of probable Alzheimer's disease, 2 possible cases of Alzheimer's disease, 2 cases of vascular dementia, and 2 cases of other types of dementia. If both members of a pair were demented, 1 was randomly selected to be included in the analyses. This procedure led to 77 dementia cases, 55 of whom had Alzheimer's disease. Both probable and possible cases of Alzheimer's disease were included. (Clinical workups of those who screened negative found only 1 to be demented. Longitudinal follow-up and rescreening with MMSE provides additional protection against the misclassification of cases and referents.)

The referents were obtained from in-person testing of participants in SATSA who were born in 1935 or earlier. To qualify as a referent, the person's MMSE score through the third wave of in-person testing (performed in 1992-1994) had to indicate that the individual was intact. To maintain the independence of all the observations, 2 reference groups were formed, allowing only 1 member of a twin pair in each group; if both members of a pair were eligible for the reference group, 1 was chosen randomly for 1 reference group and the 2 nd was assigned to the other group. Due to death or refusal, not all pairs eligible as referents were complete, and therefore the number of referents differed in the 2 groups. One reference group included 197 persons, and the other had 211 persons. Furthermore, unaffected twin partners of demented cases were not included in the reference groups, which were supplemented, one by 31 persons and the other by 27 persons, from the OCTO-twin study (30), to increase the number of older subjects. The OCTO-twin study includes all twins in the Swedish twin register in which both 
members of the pair were alive in 1992 and born 1913 or earlier. The referents from the OCTO-twin study were screened for cognitive impairment with protocols for clinical workup and diagnosis analogous to SATSA and determined to be intact. Because the OCTO-twin study and SATSA represent different subsamples of the twin register, analyses were repeated excluding the OCTO-twin referents.

Table 1 provides some descriptive information for the cases and referents. The majority of the cases, $71.4 \%$, had Alzheimer's disease, and the 2 nd largest group had vascular dementia (15.6\%). Around $10 \%$ had other types of dementia (eg, dementia secondary to Parkinson's disease or to hydrocephalus), and for 2 cases the type of dementia could not be established. The cases were born an average of approximately 10 years earlier than the referents. The average age of onset for the cases was almost the same as the average age of examination for the referents.

\section{Exposure assessment}

As part of the testing procedure for both the cases and the referents, there was an extensive, structured interview for the assessment of occupational history and exposure to potential

Table 1. Descriptive characteristics for cases of dementia and the two reference groups.

\begin{tabular}{|c|c|c|c|c|c|c|}
\hline \multirow[t]{2}{*}{ Attribute } & \multicolumn{2}{|c|}{$\begin{array}{l}\text { Cases } \\
(N=77)\end{array}$} & \multicolumn{2}{|c|}{$\begin{array}{c}\text { Reference } \\
\text { group } 1 \\
(\mathbb{N}=228)\end{array}$} & \multicolumn{2}{|c|}{$\begin{array}{l}\text { Reference } \\
\text { group } 2 \\
(N=238)\end{array}$} \\
\hline & $\mathrm{N}$ & $\%$ & $N$ & $\%$ & $\mathrm{~N}$ & $\%$ \\
\hline Alzheimer's & 55 & . & $\cdot$ & 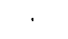 & & $\cdot$ \\
\hline Vascular dementia & 12 & . & . & . & & . \\
\hline Other dementias & 8 & . & . & . & . & . \\
\hline $\begin{array}{l}\text { Dementia not otherwise } \\
\text { specified }\end{array}$ & 2 & . & . & & . & . \\
\hline $\begin{array}{l}\text { Gender } \\
\text { Male } \\
\text { Female }\end{array}$ & $\begin{array}{l}25 \\
52\end{array}$ & $\begin{array}{l}32.5 \\
67.5\end{array}$ & $\begin{array}{r}87 \\
141\end{array}$ & $\begin{array}{l}38.2 \\
61.8\end{array}$ & $\begin{array}{r}96 \\
142\end{array}$ & $\begin{array}{l}40.3 \\
59.7\end{array}$ \\
\hline \multicolumn{7}{|l|}{ Birth year } \\
\hline $\begin{array}{l}\text { Mean } \\
\text { Median }\end{array}$ & $\begin{array}{l}1909 \\
1909\end{array}$ & & $\begin{array}{l}1920 \\
1921\end{array}$ & & $\begin{array}{l}1921 \\
1921\end{array}$ & \\
\hline \multicolumn{7}{|l|}{$\begin{array}{l}\text { Age at onset or } \\
\text { examination }\end{array}$} \\
\hline $\begin{array}{l}\text { Mean } \\
\text { Median }\end{array}$ & $\begin{array}{l}74.3 \\
75.0\end{array}$ & & $\begin{array}{l}73.1 \\
72.5\end{array}$ & & $\begin{array}{l}72.4 \\
72.0\end{array}$ & \\
\hline \multicolumn{7}{|l|}{ Gainfully employed } \\
\hline $\begin{array}{l}\text { Men } \\
\text { Women }\end{array}$ & $\begin{array}{l}25 \\
33\end{array}$ & $\begin{array}{l}100 \\
63.5\end{array}$ & $\begin{array}{r}86 \\
126\end{array}$ & $\begin{array}{l}98.9 \\
89.4\end{array}$ & $\begin{array}{r}94 \\
123\end{array}$ & $\begin{array}{l}97.9 \\
86.6\end{array}$ \\
\hline \multicolumn{7}{|l|}{$\begin{array}{l}\text { Number with measured } \\
\text { magnetic fields }\end{array}$} \\
\hline $\begin{array}{l}\text { Primary occupation } \\
\text { Last occupation }\end{array}$ & $\begin{array}{l}42 \\
45\end{array}$ & & $\begin{array}{l}151 \\
159\end{array}$ & & $\begin{array}{l}165 \\
163\end{array}$ & \\
\hline \multicolumn{7}{|c|}{ Years in primary occupation } \\
\hline $\begin{array}{l}\text { Mean } \\
\text { Median }\end{array}$ & $\begin{array}{l}29.9 \\
29.5\end{array}$ & & $\begin{array}{l}31.2 \\
30.5\end{array}$ & & $\begin{array}{l}30.3 \\
29.5\end{array}$ & \\
\hline \multicolumn{7}{|l|}{ Years in last occupation } \\
\hline $\begin{array}{l}\text { Mean } \\
\text { Median }\end{array}$ & $\begin{array}{l}24.8 \\
21.0\end{array}$ & & $\begin{array}{l}25.9 \\
24.5\end{array}$ & & $\begin{array}{l}25.1 \\
23.0\end{array}$ & \\
\hline
\end{tabular}

risk factors. An informant (most often spouse or adult offspring) was interviewed to provide information for demented cases. Job title, description of duties, place of employment, and years of employment were recorded for each occupation. A file was then created containing all occupations found in the sample. Each occupation was assigned a code based on the Nordic version of the International Standard Classification of Occupation (ISCO) manual $(31,32)$ by 2 independent coders. When different codes were assigned by the 2 coders, the decisions were reviewed and a consensus agreement was reached.

Each subject's primary occupation was defined as the occupation held the greatest number of years. The last occupation in the person's worklife was also identified, as well as the occupation with the highest magnetic field exposure.

The proportion of gainfully employed did not differ between the cases and referents among the men, but was lower among the women in the case group than among the female referents (table 1). For both the cases and referents, around $75 \%$ of the gainfully employed had occupations for which magnetic field measurements had been performed. The cases and referents had worked approximately the same amount of time in their primary occupation, as well as in their last occupation. About $33 \%$ of the cases had changed occupation between their primary and last occupation. The corresponding figure for the 1 st reference group was $36 \%$, and for the 2 nd reference group it was $31 \%$.

Information about the magnetic field exposure for each occupation was obtained from a previous case-referent study (33) in which workday measurements of magnetic fields were collected for a large number of occupations held by a sample of the general male population. A job exposure matrix was elaborated from the measurement data (34), and the file with ISCO codes was linked to this matrix. In the present study, the magnetic field level in microteslas for each occupation corresponds to the geometric mean of the arithmetic means of the workday measurements.

The measured exposures for the subjects' primary occupation, last occupation, and occupation with highest exposure were used in the analyses. Three levels of exposure were selected a priori, with cutoff points at the 1 st and 3 rd quartiles of the magnetic field distribution for primary and last occupation in the 2 reference groups combined. These cutoffs correspond to magnetic field values of $0.11 \mu \mathrm{T}$ and $0.19 \mu \mathrm{T}$. Only the subjects having an occupational history were included in the analyses. Thus groups such as housewives and students were excluded.

In addition, an expert judgment based on the job description was carried out for all occupations and classified with respect to magnetic field level into 6 exposure categories. The rating was made without knowledge of a subject's case or reference status. The estimates of the exposure were used in a series of analyses where missing measured exposures were replaced by the ratings. 


\section{Statistical methods}

The association between exposure and disease was estimated through the odds ratio. Random variability was assessed by $95 \%$ confidence intervals $(95 \% \mathrm{CI})$. All the analyses were adjusted for age, gender, and education, and they were performed with a logistic regression model (35). Age was dichotomized with median age at onset as the cutoff point $(\leq 75$, $>75$ years). Analyses were also done with a more-detailed classification of age. Education was categorized into elementary school and more than elementary school. An analysis adjusting for birth cohort was also performed, using the categories before 1910, 1911-1920, 1921 or later.

An attempt was made to perform co-twin reference analyses, in which the healthy twin partner was used as a matched referent for the demented twin in a conditional logistic regression. This approach provides a means to control for genetic and early environmental influences on the disease risk. However, the number of disease discordant pairs who were also discordant with respect to exposure were too few ( 2 pairs) to provide meaningful results.

\section{Results}

Table 2 presents the odds ratios for all types of dementia combined. For primary occupation, all the odds ratios were close to unity. For last occupation, when reference group 1 was used, the odds ratio for dementia was slightly increased in the intermediate exposure category and increased about 3fold in the highest exposure category. With the use of reference group 2, the odds ratio in the intermediate category was close to unity, whereas the risk was increased to be almost 4-fold in the highest exposure category. The analyses of higher exposure levels yielded higher, but less precise, odds ratios. With $0.5 \mu \mathrm{T}$ as the cutpoint, the odds ratio was estimated to be 5.4 (95\% CI $1.2-25.0)$ when reference group 1 was used and 13.1 (95\% CI 2.1-83.1) when reference group 2 was used. Only 2 cases and 1 subject from each reference group had magnetic field levels above $1 \mu \mathrm{T}$. For the occupation with the highest magnetic field exposure, all the odds ratios were close to unity, except for the highest exposure category when reference group 2 was used. In this case, the odds ratio was elevated but imprecise. Control of confounding from age with a more-detailed classification did not change the effect estimates, but it did yield somewhat wider confidence intervals.

Table 3 shows the corresponding results for Alzheimer's disease alone. The results were similar to the results for all dementia combined, but the odds ratios in the highest exposure category for last occupation were slightly lower than for all dementia, and less precise. For exposures of $\geq 0.5 \mu \mathrm{T}$, the odds ratio was estimated to be $4.1(95 \% \mathrm{CI} 0.7-23.5)$ when reference group 1 was used and 8.3 (95\% CI 1.1-62.7) when reference group 2 was used.

The results of the age-specific analyses for last occupation are presented in table 4 . Splitting the material into 2 age groups limited the number of cases in each analysis, but the results indicated that the association was stronger for the subjects with a younger age at onset. In the highest exposure category for subjects $\leq 75$ years of age at onset or at the time of the examination, the odds ratio for all dementia combined

Table 2. Dementia risk estimates and $95 \%$ confidence intervals $(95 \% \mathrm{Cl})$ by levels of measured occupational magnetic field exposure adjusted for age, gender, and education. ( $O R=$ odds ratio)

\begin{tabular}{|c|c|c|c|c|c|c|c|c|c|c|c|c|c|}
\hline & \multirow{2}{*}{$\begin{array}{c}\text { Level of } \\
\text { exposure } \\
(\mu T)\end{array}$} & \multicolumn{4}{|c|}{ Primary occupation } & \multicolumn{4}{|c|}{ Last occupation } & \multicolumn{4}{|c|}{ Highest exposed occupation } \\
\hline & & Cases & $\begin{array}{l}\text { Refer- } \\
\text { ents }\end{array}$ & OR & $95 \% \mathrm{Cl}$ & Cases & $\begin{array}{l}\text { Refer- } \\
\text { ents }\end{array}$ & OR & $95 \% \mathrm{Cl}$ & Cases & $\begin{array}{l}\text { Refer- } \\
\text { ents }\end{array}$ & OR & $95 \% \mathrm{Cl}$ \\
\hline $\begin{array}{l}\text { Reference } \\
\text { group } 1\end{array}$ & $\begin{array}{c}<0.12 \\
0.12-0.19 \\
\geq 0.2\end{array}$ & $\begin{array}{l}11 \\
16 \\
14\end{array}$ & $\begin{array}{l}40 \\
73 \\
37\end{array}$ & $\begin{array}{r}1 \\
1.1 \\
1.5\end{array}$ & $\begin{array}{l}0.4-2.6 \\
0.6-4.0\end{array}$ & $\begin{array}{r}9 \\
16 \\
19\end{array}$ & $\begin{array}{l}50 \\
71 \\
37\end{array}$ & $\begin{array}{r}1 \\
1.6 \\
3.3\end{array}$ & $\begin{array}{l}0.6-4.0 \\
1.3-8.6\end{array}$ & $\begin{array}{r}5 \\
18 \\
31\end{array}$ & $\begin{array}{l}15 \\
92 \\
92\end{array}$ & $\begin{array}{r}1 \\
0.7 \\
1.2\end{array}$ & $\begin{array}{l}0.2-2.3 \\
0.4-3.5\end{array}$ \\
\hline $\begin{array}{l}\text { Reference } \\
\text { group } 2\end{array}$ & $\begin{array}{c}<0.12 \\
0.12-0.19 \\
\geq 0.2\end{array}$ & $\begin{array}{l}11 \\
16 \\
14\end{array}$ & $\begin{array}{l}42 \\
82 \\
40\end{array}$ & $\begin{array}{r}1 \\
0.7 \\
1.2\end{array}$ & $\begin{array}{l}0.3-1.6 \\
0.5-3.2\end{array}$ & $\begin{array}{r}9 \\
16 \\
19\end{array}$ & $\begin{array}{l}45 \\
87 \\
31\end{array}$ & $\begin{array}{r}1 \\
0.9 \\
3.8\end{array}$ & $\begin{array}{c}0.4-2.3 \\
1.4-10.2\end{array}$ & $\begin{array}{r}5 \\
18 \\
31\end{array}$ & $\begin{array}{l}26 \\
89 \\
84\end{array}$ & $\begin{array}{r}1 \\
1.1 \\
2.1\end{array}$ & $\begin{array}{l}0.4-3.4 \\
0.7-6.2\end{array}$ \\
\hline
\end{tabular}

Table 3. Alzheimer's disease risk estimates and $95 \%$ confidence intervals $(95 \% \mathrm{Cl})$ by levels of measured occupational magnetic field exposure - adjusted for age, gender, and education. ( $O R=$ odds ratio)

\begin{tabular}{|c|c|c|c|c|c|c|c|c|c|c|c|c|c|}
\hline & \multirow{2}{*}{$\begin{array}{c}\text { Level of } \\
\text { exposure } \\
(\mu T)\end{array}$} & \multicolumn{4}{|c|}{ Primary occupation } & \multicolumn{4}{|c|}{ Last occupation } & \multicolumn{4}{|c|}{ Highest exposed occupation } \\
\hline & & Cases & $\begin{array}{l}\text { Refer- } \\
\text { ents }\end{array}$ & OR & $95 \% \mathrm{Cl}$ & Cases & $\begin{array}{l}\text { Refer- } \\
\text { ents }\end{array}$ & OR & $95 \% \mathrm{Cl}$ & Cases & $\begin{array}{l}\text { Refer- } \\
\text { ents }\end{array}$ & OR & $95 \% \mathrm{Cl}$ \\
\hline $\begin{array}{l}\text { Reference } \\
\text { group } 1\end{array}$ & $\begin{array}{c}<0.12 \\
0.12-0.19 \\
\geq 0.2\end{array}$ & $\begin{array}{r}9 \\
11 \\
7\end{array}$ & $\begin{array}{l}40 \\
73 \\
37\end{array}$ & $\begin{array}{r}1 \\
0.8 \\
0.9\end{array}$ & $\begin{array}{l}0.3-2.3 \\
0.3-2.8\end{array}$ & $\begin{array}{r}8 \\
9 \\
12\end{array}$ & $\begin{array}{l}50 \\
71 \\
37\end{array}$ & $\begin{array}{r}1 \\
1.0 \\
2.4\end{array}$ & $\begin{array}{l}0.4-2.9 \\
0.8-6.9\end{array}$ & $\begin{array}{r}4 \\
13 \\
20\end{array}$ & $\begin{array}{l}15 \\
92 \\
92\end{array}$ & $\begin{array}{r}1 \\
0.6 \\
0.9\end{array}$ & $\begin{array}{l}0.2-2.2 \\
0.3-3.2\end{array}$ \\
\hline $\begin{array}{l}\text { Reference } \\
\text { group } 2\end{array}$ & $\begin{array}{c}<0.12 \\
0.12-0.19 \\
\geq 0.2\end{array}$ & $\begin{array}{r}9 \\
11 \\
7\end{array}$ & $\begin{array}{l}42 \\
82 \\
40\end{array}$ & $\begin{array}{r}1 \\
0.6 \\
0.8\end{array}$ & $\begin{array}{l}0.2-1.7 \\
0.3-2.3\end{array}$ & $\begin{array}{r}8 \\
9 \\
12\end{array}$ & $\begin{array}{l}45 \\
87 \\
31\end{array}$ & $\begin{array}{r}1 \\
0.6 \\
2.7\end{array}$ & $\begin{array}{l}0.2-1.8 \\
0.9-7.8\end{array}$ & $\begin{array}{r}4 \\
13 \\
20\end{array}$ & $\begin{array}{l}26 \\
89 \\
84\end{array}$ & $\begin{array}{r}1 \\
1.1 \\
1.8\end{array}$ & $\begin{array}{l}0.3-3.9 \\
0.5-6.0\end{array}$ \\
\hline
\end{tabular}


Table 4. Dementia and Alzheimer's disease risk estimates and $95 \%$ confidence intervals $(95 \% \mathrm{Cl})$ by levels of measured occupational magnetic field exposure in the last occupation before onset or examination by age at onset or examination - adjusted for gender and education. ( $\mathrm{OR}=$ odds ratio)

\begin{tabular}{|c|c|c|c|c|c|c|}
\hline \multirow{2}{*}{$\begin{array}{l}\text { Age at onset or } \\
\text { examination }\end{array}$} & \multicolumn{3}{|c|}{ All dementia cases } & \multicolumn{3}{|c|}{ Alzheimer's disease cases } \\
\hline & $\mathrm{N}$ & OR & $95 \% \mathrm{Cl}$ & $N$ & $\mathrm{OR}$ & $95 \% \mathrm{Cl}$ \\
\hline \multicolumn{7}{|l|}{$\leq 75$ years } \\
\hline \multicolumn{7}{|l|}{ Level of exposure $<0.12 \mu \mathrm{T}$} \\
\hline $\begin{array}{l}\text { Reference group } 1(N=30) \\
\text { Reference group } 2(N=32)\end{array}$ & $\begin{array}{l}3 \\
3\end{array}$ & $\begin{array}{l}1 \\
1\end{array}$ & . & $\begin{array}{l}3 \\
3\end{array}$ & $\begin{array}{l}1 \\
1\end{array}$ & 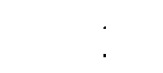 \\
\hline \multicolumn{7}{|l|}{ Level of exposure $0.12-0.19 \mu \mathrm{T}$} \\
\hline $\begin{array}{l}\text { Reference group } 1(N=48) \\
\text { Reference group } 2(N=55)\end{array}$ & $\begin{array}{l}8 \\
8\end{array}$ & $\begin{array}{l}2.2 \\
1.8\end{array}$ & $\begin{array}{l}0.5-9.3 \\
0.4-7.7\end{array}$ & $\begin{array}{l}6 \\
6\end{array}$ & $\begin{array}{l}1.8 \\
1.6\end{array}$ & $\begin{array}{l}0.4-7.9 \\
0.3-7.2\end{array}$ \\
\hline \multicolumn{7}{|l|}{ Level of exposure $\geq 0.2 \mu \mathrm{T}$} \\
\hline $\begin{array}{l}\text { Reference group } 1(N=23) \\
\text { Reference group } 2(N=26)\end{array}$ & $\begin{array}{l}13 \\
13\end{array}$ & $\begin{array}{l}5.8 \\
5.9\end{array}$ & $\begin{array}{l}1.4-23.8 \\
1.4-24.5\end{array}$ & $\begin{array}{l}10 \\
10\end{array}$ & $\begin{array}{l}4.8 \\
5.0\end{array}$ & $\begin{array}{l}1.1-21.0 \\
1.1-21.8\end{array}$ \\
\hline \multicolumn{7}{|l|}{$>75$ years } \\
\hline \multicolumn{7}{|l|}{ Level of exposure $<0.12 \mu \mathrm{T}$} \\
\hline $\begin{array}{l}\text { Reference group } 1(N=20) \\
\text { Reference group } 2(N=13)\end{array}$ & $\begin{array}{l}6 \\
6\end{array}$ & $\begin{array}{l}1 \\
1\end{array}$ & . & $\begin{array}{l}5 \\
5\end{array}$ & $\begin{array}{l}1 \\
1\end{array}$ & . \\
\hline \multicolumn{7}{|l|}{ Level of exposure $0.12-0.19 \mu \mathrm{T}$} \\
\hline $\begin{array}{l}\text { Reference group } 1(N=23) \\
\text { Reference group } 2(N=32)\end{array}$ & $\begin{array}{l}8 \\
8\end{array}$ & $\begin{array}{l}1.1 \\
0.5\end{array}$ & $\begin{array}{l}0.3-4.0 \\
0.2-1.9\end{array}$ & $\begin{array}{l}3 \\
3\end{array}$ & $\begin{array}{l}0.5 \\
0.2\end{array}$ & $\begin{array}{l}0.1-2.4 \\
0.0-1.2\end{array}$ \\
\hline \multicolumn{7}{|l|}{ Level of exposure $\geq 0.2 \mu \mathrm{T}$} \\
\hline $\begin{array}{l}\text { Reference group } 1(N=14) \\
\text { Reference group } 2(N=5)\end{array}$ & $\begin{array}{l}6 \\
6\end{array}$ & $\begin{array}{l}1.4 \\
2.5\end{array}$ & $\begin{array}{l}0.3-6.1 \\
0.5-12.3\end{array}$ & $\begin{array}{l}2 \\
2\end{array}$ & $\begin{array}{l}0.5 \\
1.0\end{array}$ & $\begin{array}{l}0.1-3.7 \\
0.1-7.4\end{array}$ \\
\hline
\end{tabular}

was estimated to be $5.8(95 \%$ CI $1.4-23.8)$ for 1 reference group and $5.9(95 \%$ CI $1.4-24.5)$ for the other. Again, the odds ratios for Alzheimer's disease were slightly lower than for all dementia combined.

The data for the men and women were analyzed separately, but there were no appreciable differences in the odds ratios between the 2 groups (results not shown). The results from the analyses excluding referents from the OCTO-twin study did not differ from the results presented in the present report, nor did the results when birth cohort was controlled (results not shown).

When the subjects in occupations for which no magnetic field measurements were available were assigned to a magnetic field exposure category according to rater judgment, the odds ratios for last occupation were lower, 2.3 (95\% CI 1.0-5.2, reference group 1) and 2.8 (95\% CI $1.2-6.5$, reference group 2) for all dementia combined at exposure levels of $\geq 0.2 \mu \mathrm{T}$. The corresponding results for Alzheimer's disease were 1.9 (95\% CI $0.8-4.5$, reference group 1) and 2.2 (95\% CI 0.9-5.5, reference group 2).

\section{Discussion}

The results of this study indicate that workers exposed to magnetic fields during their last occupation before disease onset or examination were at a higher risk of dementia, including Alzheimer's disease, than workers in low-exposure occupations. Age-specific analyses suggest that the association was stronger in those with younger ages of onset ( $\leq 75$ years). There was no support for an association between magnetic field exposure in the primary occupation and all dementias combined or for Alzheimer's disease alone. The results are not entirely consistent with previous findings. Sobel et al $(22,23)$ found an elevated risk for Alzheimer's disease for primary occupations judged to entail magnetic field exposure, and they did not evaluate risk due to exposure during last occupation.

The present findings represent advances to the literature concerning the potential association of magnetic fields and dementia. First, the study was based on twins, and, although the number of pairs was too small to permit a matched pair analysis, the results could be replicated in a 2 nd reference group. Even if the 2 reference groups were not independent, the design decreases the possibility of a chance finding. Second, the study was not restricted to patients who sought medical treatment. Unlike Sobel et al, who used vascular dementia cases as referents in some analyses in their 1st report (22) and other types of dementia as referents in their 2 nd report (23), we could estimate the risk both for all dementia and for Alzheimer's disease in particular with nondemented subjects as referents. The findings for all dementia did not simply reflect the fact that most dementia cases were Alzheimer's disease cases. When the analyses were restricted to non-Alzheimer's disease cases (the majority of which were vascular dementia), an elevated risk was also found, although these results were based on small numbers. This nonspecific effect on all dementia implies that, if the association is causal, the mechanism is probably one working on reducing the reserve 
capacity of the brain in general, and hence it makes the organism more susceptible to neurodegenerative insults rather than to a process occurring via a build-up of amyloid deposits (which would be specific to Alzheimer's disease). Thus the findings are consistent with a threshold model for the role of risk factors in dementia (21).

Third, detailed information was collected for both primary lifetime occupation and last occupation. The information enables an assessment of whether temporal proximity between exposure and age of onset is important for risk. We found both greater risk for younger age of onset and for last, but not primary, occupation. Furthermore, the risk estimates were higher for those who had less than 10 years between last occupation and the onset of disease (results not shown). These findings combined suggest that magnetic field exposure may represent a late-acting influence in the disease process and that accumulated exposure throughout the lifetime is of less importance.

Finally, there was a wide variety of occupations with elevated magnetic field exposure in the present sample (such as electrical engineer, seamstress, retail worker, forester, rail worker, machinist, postal worker, welder, etc) unlike the studies of Sobel et al $(22,23)$, in which dressmaker, tailor, and seamstress constituted the majority of the exposed professions. Workers in the textile manufacturing industry may be exposed to a large number of chemicals, such as solvents, dyes, and insecticides (36). Although the extent to which seamstresses are also exposed to these agents is unclear, confounding from 1 of these other occupational risk factors cannot be excluded (37). In contrast, the variety of occupations in the present study makes it less likely that the results can be explained by confounding from some other occupational risk factor.

For demented subjects, information about occupational history and a description of duties was obtained from a surrogate respondent, most often the spouse or adult offspring. The agreement between case and surrogate information has been shown to be high for information about last occupation, $86 \%$ agreement (38), and job description, $86 \%$ agreement (39), whereas the agreement is less for number of jobs, $33-63 \%$ agreement $(38,39)$. Use of information from surrogates may have introduced a greater misclassification of exposure for the cases than for the referents. The possibility of an association between occupational magnetic field exposure and Alzheimer's disease or dementia was not discussed when the occupational information was collected in this study. Thus systematic misclassification of the exposure is unlikely.

Only gainfully employed subjects were included in the analyses. There were no differences between the men among the cases and referents in the proportion of gainfully employed, but there were fewer gainfully employed women among the cases than among the referents, probably due to the dates of the evaluation of the cases and the referents. The screening of cases started in 1988, whereas the referents were interviewed between 1992 and 1994. As a result, the cases were born an average of approximately 10 years before the referents. The proportion of women who worked outside the household changed considerably for the later birth cohorts, the result being more gainfully employed women among those born later. There is no reason to believe that the older women were not working because they had developed symptoms of the disease.

The cases and referents did not differ regarding other aspects of their occupational histories, for example, the number of years in their primary and last occupation, and the age at which they retired. Our findings may have been due to bias had there been a decrease over time in the number of job opportunities in the exposed occupations. Owing to technological development, it seems more likely that the number of exposed jobs has increased over time, but there are no data to confirm this speculation. Furthermore, controlling for birth cohort did not change the results.

The job-exposure matrix was based on magnetic field measurements performed between 1988 and 1992, and all the measurements within a specific occupational category were summarized into an average level for that category. This procedure may have introduced misclassification of the exposure for several reasons. First, measurements of today may not be representative of past time periods; about half of the occupations were held before 1980. Second, there may be considerable variation in the magnetic field exposure within an occupational category. Third, the measurements were made on men, and therefore there may be a greater misclassification of women's exposure. However, there were no appreciable differences in the results between the men and the women. Furthermore, there is no reason to suspect differential misclassification of the exposure for the cases and referents.

In an attempt to minimize reference selection bias, the cases and the majority of the referents were identified from the same subsample of the Swedish twin register. Because the number of eligible referents above 80 years of age was too small in the original sample, some of the referents in this age group came from a different subsample from the twin register. The results of the analyses in which these referents were excluded did not differ from the results presented in this report.

The results of this study indicate that occupational magnetic field exposure may possibly influence the development of dementia. A cautious interpretation of these and previous results is, however, necessary because of the disparities of the findings. The most notable difference is that an elevated risk was found in the present study even for the diagnostic categories that were used for reference in parts of the previous studies $(22,23)$. Nonetheless, it should be noted that magnetic field exposure may be one of many risk factors for dementia, all of which may contribute to a lessening of cerebral reserve and hence to an increase in the likelihood of pathology. 


\section{Acknowledgments}

This study was supported in part by the Swedish Work Environment Fund (no 95 - 0240), by grants from the National Institute of Aging, in the United States (AG-08754, AG10175, AG-08861), and the John D and Catherine T MacArthur Foundation.

We thank Johan Hedbäck for his help with the ISCO coding and Tomas Lindh for his help with the exposure ratings.

\section{References}

1. Iqbal K, Mortimer JA, Winblad B, Wisniewski HM. Research advances in Alzheimer's disease and related disorders. Chichester (England): John Wiley \& Sons, 1995.

2. Larsson T, Sjögren T, Jacobson G. Senile dementia: a clinical, sociomedical and genetic study. Acta Psychiatr Scand 1963;39 suppl $167: 1-259$.

3. Goate A, Chartier-Harlin M, Mullan M, Brown J, Crawford F, Fidani $\mathrm{L}$, et al. Segregation of a missense mutation in the amyloid precursor protein gene with familial Alzheimer's disease. Nature 1991; $347: 704-6$

4. Sherrington R, Rogaev EI, Liang Y, Rogaeva EA, Levesque G, Ikeda $\mathrm{M}$, et al. Cloning of a gene bearing missense mutations in earlyonset familial Alzheimer's disease. Nature 1995;375:754_60.

5. Levy-Lahad E, Wasco W, Poorkaj P, Romano DM, Oshima J, Pettingell WH, et al. Candidate gene for the chromosome 1 familial Alzheimer's Disease locus. Science 1995;269:973-7.

6. van Duijn CM, Clayton D, Chandra V, Fratiglioni L, Graves AB, Heyman A, et al. Familial aggregation of Alzheimer's disease and related disorders: a collaborative re-analysis of case-control studies. Int J Epidemiol 1991;20 suppl 2:13-20.

7. Fratiglioni L, Jorm AF, Grut M, Viitanen M, Holmén K, Ahlbom A, et al. Predicting dementia from the Mini-Mental State Examination in an elderly population: The role of education. J Clin Epidemiol 1993;46:281-7.

8. Gatz M, Pedersen NL, Berg S, Johansson B, Johansson K, Mortimer JA, et al. Heritability for Alzheimer's disease: the study of dementia in Swedish twins. J Gerontol Med Sci 1997;52A:M117-25.

9. Breitner JCS, Welsh KA, Gau BA, McDonald WM, Steffens DC, Saunders AM, et al. Alzheimer's disease in the National Academy of Sciences-National Research Council Registry of Aging Twin Veterans: III. detection of cases, longitudinal results, and observations on twin concordance. Arch Neurol 1995;52:763-71.

10. Bergem ALM. Heredity in dementia of the Alzheimer type. Clin Genet 1994;46:144 9 .

11. Corder EH, Saunders AM, Strittmatter WJ, Schmechel DE, Gaskell $\mathrm{PC}$, Small GW, et al. Gene dose of apolipoprotein E type 4 allele and the risk of Alzheimer's disease in late onset families. Science 1993;261:921-3.

12. Kamboh MI, Sanghera DK, Ferrell RE, DeKosky ST. APOE*4-associated Alzheimer's disease risk is modified by $\alpha 1$ - antichymotrypsin polymorphism [letter]. Nat Genet 1995;10:486-8.

13. Hardy J. Alzheimer's disease: clinical molecular genetics. Clin Geriatr Med 1994;10:239—47.

14. Breteler MMB, van Duijn CM, Chandra V, Fratiglioni L, Graves $\mathrm{AB}$, Heyman A, et al. Medical history and the risk of Alzheimer's disease: a collaborative re-analysis of case-control studies. Int J Epidemiol 1991;20 suppl 2:36—-42.
15. Jorm AF, van Duijn CM, Chandra V, Fratiglioni L, Graves AB, Hey$\operatorname{man} A$, et al. Psychiatric history and related exposures as risk factors for Alzheimer's disease: a collaborative re-analysis of case-control studies. Int J Epidemiol 1991;20 suppl 2:43-7.

16. van Duijn CM, Stijnen T, Hofman A. Risk factors for Alzheimer's disease: overview of the EURODEM collaborative re-analysis of case-control studies. Int J Epidemiol 1991;20 suppl 2:4-S12.

17. Breitner JCS, Gau BA, Welsh KA, Plassman BL, McDonald WM, Helms MJ, et al. Inverse association of anti-inflammatory treatments and Alzheimer's disease: initial results of a co-twin control study. Neurology 1994:44:227-32.

18. Henderson V, Paganini-Hill A, Emanuel C, Dunn M, Buckwalter JG. Estrogen replacement therapy in older women: comparisons between Alzheimer's disease cases and nondemented controls. Arch Neurol 1994;51:896-900.

19. Mortimer JA, Graves AB. Education and other socioeconomic determinants of dementia and Alzheimer's disease. Neurology 1993;43:839-44.

20. Mortimer JA, van Duijn CM, Chandra V, Fratiglioni L, Graves AB, Heyman A, et al. Head trauma as a risk factor for Alzheimer's disease: a collaborative re-analysis of case-control studies. Int J Epidemiol 1991;20 suppl 2:28-35.

21. Mortimer JA. What are the risk factors for dementia? In: Huppert FA, Brayne C, O'Connor D, editors. Dementia and normal ageing. Cambridge: Cambridge University Press, 1994:208-29.

22. Sobel E, Davanipour Z, Sulkava R, Erkinjuntti T, Wikstrom J, Henderson VW, et al. Occupations with exposure to electromagnetic fields: a possible risk factor for Alzheimer's disease. Am J Epidemiol 1995;142:515-24.

23. Sobel E, Dunn M, Davanipour Z, Qian Z, Chin HC. Elevated risk of Alzheimer's disease among workers with likely electromagnetic field exposure. Neurology 1996;47:1477—81.

24. Pedersen NL, McClearn GE, Plomin R, Nesselroade JR, Berg S, de Faire U. The Swedish adoption twin study of aging: an update. Acta Genet Med Gemellol (Roma) 1991;40:7-20.

25. Folstein MF, Folstein SE, McHugh PR. Mini Mental State: a practical method for grading the cognitive state of patients for the clinician. J Psychiatr Res 1975;12:189-98.

26. Gatz M, Reynolds C, Nikolic J, Lowe B, Karel M, Pedersen N. An empirical test of telephone screening to identify potential dementia cases. Int Psychogeriatrics 1995;7:429-38.

27. Morris JC, Heyman A, Mohs RC, Hughes JP, van Belle G, Fillenbaum $\mathrm{G}$, et al. The consortium to establish a registry for Alzheimer's disease (CERAD), part I: clinical and neuropsychological assessment of Alzheimer's disease. Neurology 1989;39:1159—65.

28. American Psychiatric Association. Diagnostic and statistical manual of mental disorders. 3rd ed, revised. Washington (DC): American Psychiatric Association, 1987.

29. McKhann G, Drachman D, Folstein M, Katzman R, Price D, Stadlan EM. Clinical diagnosis of Alzheimer's disease: report of the NINCDS-ADRDA work group under the auspices of Department of Health and Human Services Task Force on Alzheimer's disease. Neurology 1984;34:939-44.

30. Berg S, Johansson B, Plomin R, Ahem FM, Pedersen NL, McClearn GE. Origins of variance in the old-old: the first presentation of the OCTO-twin study in Sweden. Behav Genet 1992;22:708-9.

31. International Labour Office (ILO). International standard classification of occupations. Geneva: ILO, 1958.

32. Statistiska Centralbyrån. Folk och Bostadsräkningen 1980 [Population and housing census 1980]. Örebro, Sweden: Statistiska Centralbyrån, Enheten för befolkningsstatistik, 1983.

33. Floderus B, Persson T, Stenlund C, Wennberg A, Öst $\AA$, Knave B. Occupational exposure to electromagnetic fields in relation to leukemia and brain tumors: a case-control study in Sweden. Cancer 
Causes Control 1993;4:465-76.

34. Floderus B, Persson T, Stenlund C. Magnetic-field exposures in the workplace: reference distribution and exposures in occupational groups. Int J Occup Environ Health 1996;2:226-38.

35. Breslow NE, Day NE. The analysis of case-control studies. Lyon: International Agency for Research on Cancer (IARC), 1980. LARC statistical methods in cancer research, vol 1.

36. International Agency for Research on Cancer (IARC). Some flame retardants and textile chemicals, and exposure in the textile manufacturing industry. 48th ed. Lyon: IARC, 1990:215-34. IARC monographs on the evaluation of carcinogenic risks to humans.

37. Kukull WA, Larson EB, Bowen JD, McCormick WC, Teri L, Pfanschmidt ML, et al. Solvent exposure as a risk factor for Alzheimer's disease: a case-control study. Am J Epidemiol 1995; 141:105971.

38. Rocca WA, Fratiglioni L, Bracco L, Pedone D, Groppi C, Schoenberg $\mathrm{B}$. The use of surrogate respondents to obtain questionnaire data in case-control studies of neurologic diseases. J Chronic Dis $1986 ; 39: 907-12$

39. Chong JP, Turpie I, Haines T, Muir G, Farnworth H, Cruttenden K. Concordance of occupational and environmental exposure information elicited from patients with Alzheimer's disease and surrogate respondents. Am J Ind Med 1989;15:73-89.

Received for publication: 10 June 1997 